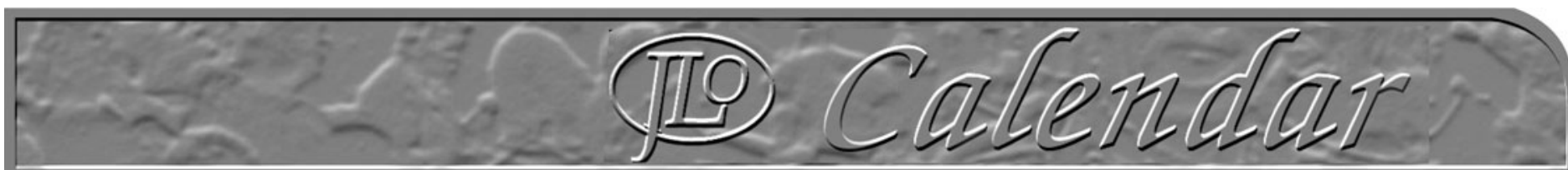

\title{
EVENTS, COURSES AND CONFERENCES
}

\section{0}

\section{March}

62nd Annual General and

Scientific Meeting of the New

Zealand Society of Otolaryngology,

Head and Neck Surgery

"Practical ENT - Insights and Perspectives"

March 2-5, 2010

Paihia, Bay of Islands, New Zealand

Online information: www.orl2010.org.nz

Conference Managers: Workz4U Conference

Management

Tel: + 6499173653

E-mail: events@workz4u.co.nz

Website: www.workz4uconferences.co.nz

The Joint Newcastle/GIR course

for the Intercollegiate

FRCS examination in

Otolaryngology

March 3-5, 2010

Newcastle, UK

Contact: Victoria Richardson

Tel: + 44 (0)191 2137634

E-mail: victoria.richardson@ nuth.nhs.uk

4th EHNS European

Conference on Head and

Neck Oncology

March 4-6, 2010

Athens, Greece

Website: www.ehns2010-anthens.com

\section{April}

Temporal Bone Surgical Dissection

5-Day Course

April 12-16, 2010

Michigan, USA

E-mail: leldred@umich.edu

Website: www med umich.edu/oto/

otoneuro/Bonelabbrochure.pdf

13th Course on Ear and Temporal

Bone Surgery

April 13-16, 2010

Hannover, Germany

Tel: + 495115323936

Fax + 495115325558

E-mail: pettig.sylvia@mh-hannover.de

\section{May}

Combined Universities Course

in Advanced Surgical Otology

May 3-6, 2010

Edinburgh, UK

Contact: Julie Murray

Tel: + 44 (0) 139446113

E-mail: info@scm-ltd.com

International Mastercourse on

Endoscopic Sinus Surgery

May 5-8, 2010

Brussels, Belgium

E-mail: karine.nuyts@uzbrussel.br

Web: www.everyoneweb.com/iMESS2010

\section{June}

Beyond Newborn Hearing

Screening: Infant and Childhood

Hearing in Science and Clinical

Practice

June 8-10, 2010

Cernobbio, Italy

Contact: Sharon Scagnetti

E-mail: nhs@polimi.it

4th International TRI Tinnitus

Conference

June 9-11, 2010

Dallas, USA

Website: tinnitusresearch.org

4th World Congress of

International Federation of Head

and Neck Oncologic Societies

June 15-19, 2010

Seoul, Korea

Tel: + 82220822310

E-mail: ifhnos2010@meci.co.kr

Website: www.ifhnos2010.org

IV Consensus in Auditory

Implants

June 16-19, 2010

Parma, Italy

Tel: + 39 (0) 521290191

E-mail: Giulia@mvcongressi.it

\section{July}

12th International Otology Course July 1-3, 2010

Beziers, France
Tel: +33467356395

E-mail: contact@Clinique-causse.com

Website: Clinique-causse.com

\section{September}

8th Congress of European

Laryngological Society

September 2-9, 2010

Vienna, Austria

Website: elsoc.org

The 4th World Voice Congress

September 6-9, 2010

Seoul, Korea

Contact: Secretariat

Tel: + 8225666067

Fax: + 8225666087

E-mail: seoul@voice2010 org

Website: www voice2010.org

114th American Academy of ORL, Head \& Neck Surgery

Annual Meeting \& OTO EXPO

September 26-29, 2010

Boston, USA

Contact: Marketing Co-ordinator

E-mail: aaomeet@entnet.org

Website: www.entnet.org

\section{October}

Current Concepts in Head and

Neck Surgery and Oncology

October 3-5, 2010

Frankfurt, Germany

Website: ifhnosworldtour2010.org

\section{5th EUHA Congress}

October 13-15, 2010

Hanover, Germany

Tel: + 49 (0) 61 31/28 30-0

E-mail: info@euha.org

Website: euha.org

\section{1}

\section{March}

Asia-Oceania ORL-HNS

\section{Congress}

March 1-4, 2011
Auckland, New Zealand

Website: asia-oceania2011.org

\section{June}

10th European Federation of Audiology Societies and

6th Annual Conference of the

Audiology and Phoniatrics Section

of the Polish Society

June 22-26, 2011

Warsaw, Poland

Website: efas2011.org

\section{2}

\section{May}

12th International Conference on Cochlear Implants and other Implantable Auditory

Technologies

May 3-5, 2012

Baltimore, USA

E-mail: corinnea@cmcglobal.com

Website: ci-2012 com

\section{June}

24th Congress of the European Rhinologic Society

June 17-21, 2010

Toulouse, France

Tel: + 33534452645

Fax: + 33534452646

E-mail: registers@europa-organisation.com

\section{July}

BACO 2012

July 4-6, 2010

Glasgow, UK

Website: entuk.org 


\section{CAMBRIDGE JDLNALS}

\section{Bulk Article Reprints}

Reprints of articles published in this journal can be purchased for use by your company or organisation. These reprints can be produced as straight article reprints or with custom designed covers and, if required, the sponsor's name printed on or inside the cover. Reprints represent a versatile sales tool for the distribution of up-to-date information on your particular areas - via your sales force, direct mail campaigns and as handouts at major conferences and commercial exhibitions. Reprints can usually be delivered to clients $2-4$ weeks after the receipt of the order.

\section{Rebecca Curtis, Special Sales Manager}

Cambridge University Press, The Edinburgh Building,

Shaftesbury Road, Cambridge, UK, CB2 8RU

Tel: +44 (0)1223 325757, Email: special_sales@cambridge.org

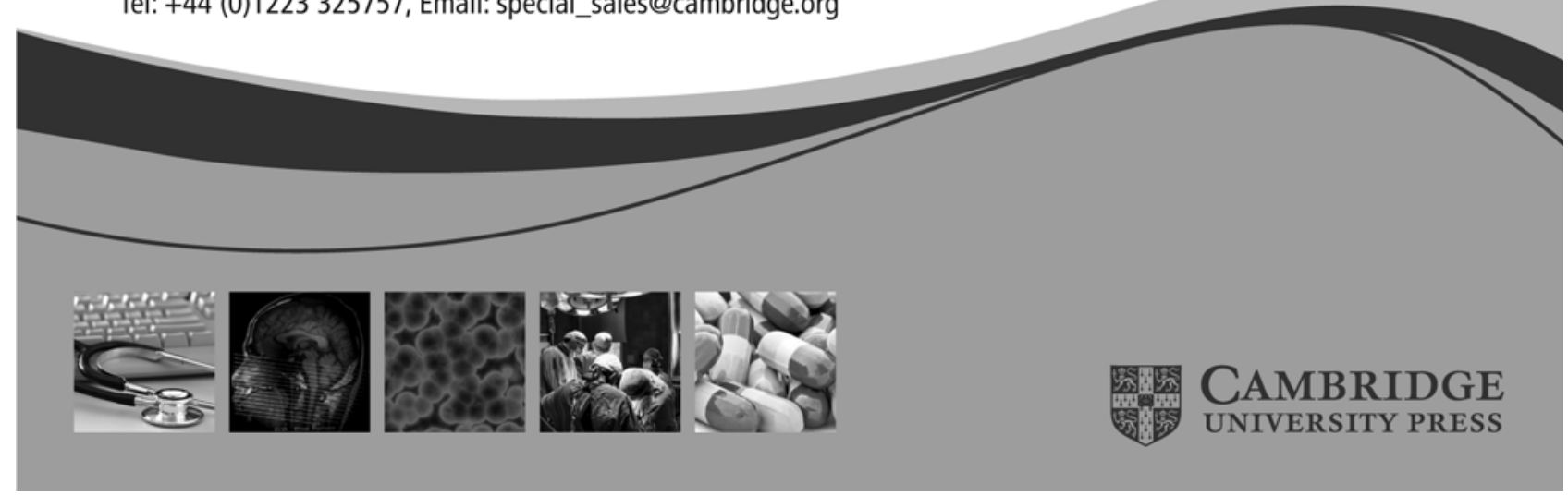

The Trustees of JLO (1984) Ltd are seeking suitable candidates for the post of Joint Editor of The Journal of Laryngology and Otology when Guy Kenyon leaves office later in 2010. Applications would be welcomed, from appropriately qualified individuals, in the form of a curriculum vitae and a short statement of relevant experience in journal publishing.

\section{Applications should be sent to Rosamund Greensted (j.1.o@btconnect.com) by 19th March 2010}




\section{The Journal of Laryngology \& Otology}

Vol 124

March 2010

\section{Review Articles}

Simulation in ENT medical education: K-EA Abou-Elhamd, Al Al-Sultan, UM Rashad

Endoscopic sinus surgery: evolution and technical innovations: $S$ Govindaraj, ND Adappa, DW Kennedy

\section{Main Articles}

Vestibular schwannoma: role of conservative management: $R$ Suryanarayanan, RT Ramsden, SR Saeed, R Aggarwal, AT King, SA Rutherford, DG Evans, JE Gillespie

Vestibular schwannoma: when to look for it?: $S$ Gimsing

Changes in facial nerve function, morphology and neurotrophic factor expression in response to three types of nerve injury: $L$ Zhang, Z Fan, $Y H a n, L X u, J L u o, J L i, H W a n g$

Facial nerve decompression for idiopathic Bell's palsy: report of 13 cases and literature review: C Bodénez, I Bernat, J-C Willer, P Barré, G Lamas, F Tankéré

Topical 5-fluorouracil for granular myringitis: a double-blinded study: AM Atef, MM Hamouda, AH Amohamed, AFA Fattah

Dizziness, migrainous vertigo and psychiatric disorders: $R$ Teggi, $D$ Caldirola, $B$ Colombo, G Perna, G Comi, L Bellodi, M Bussi

Three-dimensional reconstruction based on computed tomography images of the frontal sinus drainage pathway: SD Reitzen, EY Wang, SR Butros, J Babb,

RA Lebowitz, JB Jacobs

Does regional pollen load affect the prevalence of clinical allergy to those pollen groups?: IH Can, A İslam, DS Karasoy, EE Samim

Frequency and management of epistaxis in schools: $A$ Robertson, $R$ King, A Tomkinson

The 14-item Paediatric Throat Disorders Outcome Test: a valid, sensitive, reliable, parent-reported outcome measure for paediatric throat disorders: C Hopkins, J Fairley, M Yung, I Hore, S Balasubramaniam, M Haggard

Significance of free radical injury in laryngeal and hypopharyngeal cancers: MK Manjunath, $\checkmark$ Annam, DR Suresh

GSTT1, GSTM1, GSTM3 and NAT2 polymorphisms in laryngeal squamous cell carcinoma in a Greek population: M Chatzimichalis, J Xenellis, A Tzagaroulakis, $P$ Sarof, K Banis, M Gazouli, A Bibas

Readability of out-patient letters copied to patients: can patients understand what is written about them?: SL Todhunter, PJ Clamp, S Gillett, DD Pothier

\section{Short Communications}

Novel use of ultrasound-guided endo-cavitary probe to evaluate an impalpable parapharyngeal mass: A Riskalla, A Arora, F Vaz, $P$ O'Flynn

Laryngeal sensory testing in the assessment of patients with laryngopharyngeal reflux: OT Dale, O Alhamarneh, $K$ Young, $S$ Mohan

\section{Clinical Records}

Head rotation evoked tinnitus due to superior semicircular canal dehiscence: E-C Nam, R Lewis, HH Nakajima, SN Merchant, RA Levine

Recurrent laryngeal nerve paralysis due to subclinical Lyme borreliosis: $T$ Karosi, T Racz, É Szekanecz, Á Toth, I Sziklai

An unusual cause of pre-auricular swelling: AT Harris, I Bhatti, Y Bajaj, GJC Smelt

Duplication of internal jugular veins: case report: BYW Wong, DR Strachan, EL Loney

Polypoid intranasal mass caused by Rosai-Dorfman disease: a diagnostic pitfall: M Ilie, N Guevara, L Castillo, P Hofman

Multinodular goitre in lingual thyroid: case report: M Zackaria, EJ Chisholm, NS Tolley, A Rice, A Chhatwani 